\title{
Root Growth of Arabidopsis thaliana (L.) Heynh. treated with humic acids isolated from typical soils of Rio de Janeiro State, Brazil
}

\author{
Marihus Altoé Baldotto ${ }^{1 *}$, Rafael Carvalho Muniz ${ }^{2}$, Lílian Estrela Borges Baldotto ${ }^{1}$, Leonardo Barros Dobbss ${ }^{3}$
}

\begin{abstract}
Humic substances isolated from soil organic matter had been used as stimulators of plant metabolism. Arabidopsis thaliana (L.) Heynh. with only five chromosomes, short cycle and size, is an important model to evaluate the physiological effects of these substances, which are qualitatively and quantitatively influenced by morphogenesis, mineralogy and chemistry of soils. The objective of this study was to evaluate the ambience effects on bioactivity of humic acids. A and B horizons of four typical soils of the North Fluminense were sampled. After isolation and purification, humic acids were applied to plants in increasing concentrations. The number and length of lateral roots and main root length were evaluated and, subsequently, the concentrations of maximum stimulation were determined by dose-response curves and regression equations. The results showed that more stable humic acids isolated from soil in less advanced stages of weathering, high activity clay and high base saturation resulted in better physiological stimulants for Arabidopsis.
\end{abstract}

Key words: Soil genesis, chemistry and fertility, humic substances, bioactivity, Arabidopsis thaliana.

\section{RESUMO}

\section{Crescimento radicular de plantas de Arabidopsis thalaiana tratadas com ácidos húmicos isolados de diferentes solos típicos do Estado do Rio de Janeiro}

As substâncias húmicas isoladas da matéria orgânica do solo têm sido usadas como estimuladores do metabolismo vegetal. As plantas de Arabidopsis thaliana (L.) Heynh. com apenas cinco cromossomos, ciclo curto e tamanho reduzido, aparecem como modelo para avaliar os efeitos fisiológicos dessas substâncias, as quais são qualitativa e quantivamente influenciadas pela morfogênese, mineralogia e química dos solos. Avaliar os efeitos dessas ambiências na bioatividade de ácidos húmicos foi o objetivo principal do presente trabalho. Para isso, foram amostrados os horizontes A e B de quatro solos típicos da Região Norte Fluminense. Após o isolamento e purificação, ácidos húmicos foram usados em concentrações crescentes nas plantas. O número e comprimento de raízes laterais e o comprimento da raiz principal foram avaliados e, posteriormente, determinadas as concentrações de máxima estimulação, obtidas por meio das curvas de dose resposta e das equações de regressão ajustadas. Os resultados mostraram que ácidos húmicos mais estáveis, isolados de solos em estádio de intemperismo menos avançado, com argila de alta atividade e alta saturação por bases resultaram em melhores estimulantes fisiológicos das plantas de Arabidopsis.

Palavras-chave: Gênse, química e fertilidade do solo, substâncias húmicas, bioatividade, Arabidopsis thaliana.

\footnotetext{
Recebido para publicação em 01/06/2010 e aprovado em 06/07/2011

${ }^{1}$ Agronomist Engineers, Doctor Science. Universidade Federal de Viçosa, Campus de Florestal, 35.690-000, Florestal, MG, Brazil. marihus@ufv.br; lilian.estrela@ufv.br. *Corresponding author: marihus@ufv.br.

Grant holder at the Laboratório de Solos, do Centro de Ciências e Tecnologias Agropecuárias (CCTA), da Universidade Estadual do Norte Fluminense Darcy Ribeiro (UENF). Av. Alberto Lamego, 2000, 28013-602, Campos dos Goytacazes, RJ, Brazil.

Agronomist Engineer, Doctor Science. Centro Universitário de Vila Velha, Laboratório de Microbiologia Ambiental e Biotecnologia, Rua Comissário José Dantas de Melo 21, Boa Vista, 29102-770 - Vila Velha, ES, Brazil.
} 


\section{INTRODUCTION}

In the soil, the chemical stability of organic matter occurs with the formation of humic substances via humification. These substances are considered to be supra molecular aggregates organized in groups of various low molecular weigh organic compounds, containing predominantly hydrophilic (fulvic acid) or hydrophobichydrophilic (humic acids) domains (Piccolo, 2001). In natural systems, there is a mixture of these domains. These aggregates are maintained in solution by hydrogen bonds and hydrophobic interactions which, alone, are weak, but, together, provide structure to these substances and result in apparent high molecular weight. When, operationally, ionization is promoted using alkali extractants, both groups are dissolved, whereas acidification provides precipitation of humic acids only, which are less polar and more hydrophobic than fulvic acids, therefore more stable in the environment (Sposito, 2008). Thus, humic acids, as an intermediate fraction between the fulvic acids, more hydrophilic and soluble, and humin, more hydrophobic and insoluble, are listed as indicators of organic matter stability in the soil (Baldotto et al., 2010). Because their conformation and structure vary with environmental conditions, e.g., ionic strength and $\mathrm{pH}$, they have the properties of biomolecules from which they are derived (Sposito, 2008) in their supra molecular arrangement, which stimulate plant growth (Façanha et al., 2002).

The use of humic acids in promoting plant growth and development is well documented (Baldotto et al., 2009). These substances favor growth (Canellas et al., 2002, 2004, 2006; Rodda et al. 2006; Zandonadi et al. 2007; Dobbss et al. 2007; Canellas et al., 2008a) and nutrient accumulation in several plants of agronomic interest (Vaughan \& Malcolm, 1985; Chen \& Avaide, 1990; Chen et al., 2004). These effects reflect in the increase of root growth rate, increases in plant biomass and root architectural changes (root hairs and thin lateral roots), resulting in increased surface area and/or in root length (Canellas et al., 2006). Leaf application of humic acids has been reported to promote growth in rice (Tejada \& Gonzalez, 2004), wheat (Delfine et al., 2005) and vine (Ferrara $\&$ Brunetti, 2008). In pineapple, the use of humic acids proved to be a practical in the acclimatization of plants propagated in vitro (Baldotto et al., 2009).

Besides growth and nutritional aspects, possible physiological effects were shown by the quantification of photosynthetic pigments in the presence of humic acids by Baldotto et al. (2009). Treatment with humic acids provided higher levels of the photosynthetic pigments and significant increase in the ratio of chlorophyll $a$ and $b$, as compared with the control. These results indicated that application of humic acid increases plant growth rate during acclimatization of plants propagated in vitro, favoring the establishment of plants in environment $e x$ vitro and the subsequent establishment in the field. This can be an important alternative for reducing production costs, based on more efficient nutrient absorption and growth.

Most biostimulant effects of humic acids have been attributed to their activity similar to the plant hormone auxin, i.e. they can promote plant growth in relatively small concentrations. Some mechanisms of action have been proposed to explain the induction of root growth by humic acids, such as the formation of soluble complexes with cations in the rhizosphere (Chen \& Avaide, 1990) and a presumed increased permeability of the plasma membrane by the surfactant action of humic acids (Canellas et al., 2006). If, on the one hand, change in selective permeability of the plasmalemma, in theory, can increase the ion entry, on the other hand, it may also favor the exit, since the surfactant action does not preserve membrane selectivity (Nardi et al., 2002).

Canellas et al. (2008a, b) found that corn seedlings treated with humic acids change their growth profile and root exudation of organic acids, significantly increasing the extrusion of citric and oxalic acids. When in contact with the acidic rhizosphere environment, super-structural particles of humic acids can break and generate subunits that can potentially change the cellular metabolism through activation of $\mathrm{H}^{+}$-ATPases of the plasma membrane in root cells (Piccolo, 2001; Façanha et al., 2002). These mechanisms lead to apoplast acidification and activation of cell wall-degrading exoenzymes, making the wall more susceptible to the action of vacuolar turgor pressure. This causes cell expansion and, consequently, root tissue expansion (Hager et al. 1991; Frias et al., 1996).

Arabidopsis thaliana is an important model system for studying plant physiological processes, because it offers many advantages such as small size, short life cycle and small genome (Sommerville \& Meyerowitz, 2002). This study aimed to quantify the stimulating action of humic acids isolated from typical soils of the State of Rio de Janeiro, Brazil, with different morphogenetic characteristics, mineralogical and chemical characteristics influencing the Arabidopsis root system.

\section{MATERIALS AND METHODS Soil samples}

Soils from different classes, under common grass/ pasture use, in the State of Rio de Janeiro were selected for this study. Samples were collected from surface and subsurface layers (horizons A and B). The samples consisted of the following soils' classes (Embrapa, 2006): Argilluvic Orthic Vertic Chernosol (Chernosol), Chromic 
Palic Abruptic Luvisol (Luvisol), Dystrophic Red Yellow Acrisol (Acrisol), Typical Cohesive Yellow Latosol (Latosol), representing a typical sequence of the North Fluminense landscape.

The soils were sampled along the highway ItaperunaCampos dos Goytacazes and described during the First Meeting of Classification and Correlation of Soils (Embrapa, 1980). Table 1 shows some characteristics of the soils. Aspects of genesis and chemistry of these soils and their relation to organic carbon stocks of are described in Baldotto et al. (2010).

\section{Extraction and purification of humic acids}

Humic acids were isolated from soils according to the recommendations of the International Humic Substance Society (IHSS, 2009), using $\mathrm{NaOH} 0.1 \mathrm{~mol} \mathrm{~L}^{-1}$ under $\mathrm{N}_{2}$ atmosphere, in the soil:extractor ratio $1: 10$ (mass:volume ). The material was stirred for $24 \mathrm{~h}$ and centrifuged at 5,000 $\mathrm{g}$ for $30 \mathrm{~min}$. The supernatant was collected and the $\mathrm{pH}$ of the extract was immediately adjusted to 1.5 with $\mathrm{HCl} 6 \mathrm{~mol} \mathrm{~L}^{-1}$. After $18 \mathrm{~h}$, the fulvic acid fraction was siphoned and discarded. The remaining material (precipitated humic acids) was dissolved in $\mathrm{NaOH}$ $0.1 \mathrm{~mol} \mathrm{~L}^{-1}$ and centrifuged at 5,000 $\mathrm{g}$ for $10 \mathrm{~min}$ and the precipitate (clay) discarded. Solubilization and reprecipitation of humic acids was repeated twice. The precipitate of humic acids was dissolved and remained in $5 \% \mathrm{HF}+\mathrm{HCl}$ for $48 \mathrm{~h}$, to remove residues of clay minerals and paramagnetic ions, and then centrifuged at $5,000 \mathrm{~g}$. Humic acids were washed with $200 \mathrm{~mL}$ of $\mathrm{HCl} 0.01$ mol L-1 and centrifuged at 5,000 g. The precipitate was washed with distilled water until a negative test for $\mathrm{Cl}^{-}$, using $0.1 \mathrm{~mol} \mathrm{~L}^{-1} \mathrm{AgNO}_{3}$ and transferred to $10 \mathrm{~mL}$ dialysis membranes (cut-off $14 \mathrm{KDa}$, Thomas Sci.) to reach electrical conductivity of distilled water $\left(1.0 \mu \mathrm{S} \mathrm{cm}^{-1}\right)$. After dialysis, humic acids were freeze-dried and stored in desiccators.

\section{Bioactivity of humic acids}

Evaluation of humic acids bioactivity followed was according to the protocol by Dobbss et al. (2007). Seeds of Arabidopsis thaliana, ecotype Columbia 4 (co4), were sterilized in $95 \%$ ethanol (v/v) for $5 \mathrm{~min}$, in $20 \% \mathrm{NaClO}$ for $7 \mathrm{~min}$, and washed five times with distilled water. Seeds were sown in plastic plates in the vertical position lined with one layer of filter paper and one layer of synthetic fine mesh fabric (poliprint). Both the top and the bottom of this structure remained open and covered with black plastic to prevent roots from being exposed to light. After sowing, the plates were incubated at $8^{\circ} \mathrm{C}$ in the dark, for $24 \mathrm{~h}$, and transferred to growth room at $25^{\circ} \mathrm{C}, 90 \mu \mathrm{mol} \mathrm{m} \mathrm{m}^{-2} \mathrm{~s}^{-1}$ photosynthetic photon flux density and a $14 \mathrm{~h}$ photoperiod.

The cultivation system consisted of immerging the plates containing pre-germinated seedlings in a water tank in the first five days. Five days after germination, the seedlings were thinned to four plants per plate, and Hoogland solution modified to a final concentration of 1 mmol L-1 $\mathrm{N}$ was applied (Dobbss et al., 2007). Four $\mathrm{mL}$ of solution containing $0,20,40$ and $80 \mathrm{mg} \mathrm{L}^{-1}$ of humic acids were added to each plate and $4 \mathrm{~mL}$ of deionized water only to the control treatment. After the treatments, the plates were incubated into the water reservoir for $48 \mathrm{~h}$ and, then, the nutrient solution was added. Two weeks later, the plates were stained with toluidine blue $(0.05 \%)$ and scanned (600 dpi) for root analysis through an image electronic processing. Two plants corresponding to the central position of each plate were used for the analysis. Evaluation of change in root architecture considered the number of lateral roots, lateral root length and main root length.

\section{Data analysis}

Means of the analysis performed in duplicate and standard errors of means were estimated for each experimen-

Table 1. Chemical analysis of soils of the State of Rio de Janeiro

\begin{tabular}{|c|c|c|c|c|c|c|c|c|c|c|c|c|c|c|}
\hline Soil class & $\begin{array}{l}\text { Corg } \\
\mathrm{g} \mathrm{kg}^{-1}\end{array}$ & pH & $\begin{array}{c}\mathbf{P} \\
-\mathrm{mg} \mathrm{dm}\end{array}$ & ${ }^{\mathbf{K}}$ & $\mathrm{Ca}^{2+}$ & $\mathbf{M g}^{2+}$ & $\mathrm{Na}^{+}$ & $\mathbf{A l}^{3+}$ & $\begin{array}{c}\mathbf{H}+\mathbf{A l} \\
\mathrm{mol}_{\mathrm{c}} \mathrm{dm}^{-3}\end{array}$ & SB & $\mathbf{T}$ & $\mathbf{t}$ & $\mathbf{m}$ & $\begin{array}{l}\mathbf{V} \\
\%\end{array}$ \\
\hline \multicolumn{15}{|l|}{ A Horizon } \\
\hline Chernosol & 17.2 & 6.6 & 7 & 83 & 18.2 & 0.4 & 0.10 & 0.0 & 2.8 & 18.9 & 21.7 & 18.9 & 0 & 87 \\
\hline Luvisol & 16.2 & 6.6 & 7 & 38 & 9.9 & 0.2 & 0.06 & 0.0 & 2.4 & 10.3 & 12.7 & 10.3 & 0 & 81 \\
\hline Acrisol & 13.6 & 6.4 & 5 & 60 & 4.7 & 2.6 & 0.09 & 0.0 & 3.3 & 7.5 & 10.8 & 7.5 & 0 & 70 \\
\hline Latosol & 13.1 & 5.5 & 5 & 74 & 1.8 & 1.9 & 0.09 & 0.1 & 4.6 & 4.0 & 8.6 & 4.1 & 2 & 46 \\
\hline \multicolumn{15}{|l|}{ B Horizon } \\
\hline Chernosol & 7.9 & 7.0 & 2 & 36 & 16.9 & 0.5 & 0.09 & 0.0 & 1.4 & 17.6 & 19.0 & 17.6 & 0 & 93 \\
\hline Luvisol & 5.1 & 6.4 & 5 & 14 & 3.0 & 0.5 & 0.08 & 0.0 & 1.3 & 3.6 & 4.9 & 3.6 & 0 & 74 \\
\hline Acrisol & 3.0 & 5.9 & 2 & 17 & 3.0 & 1.9 & 0.07 & 0.0 & 1.9 & 5.0 & 6.9 & 5.0 & 0 & 73 \\
\hline Latosol & 3.0 & 4.7 & 1 & 7 & 0.3 & 1.0 & 0.09 & 0.4 & 2.9 & 1.4 & 4.3 & 1.8 & 22 & 33 \\
\hline
\end{tabular}

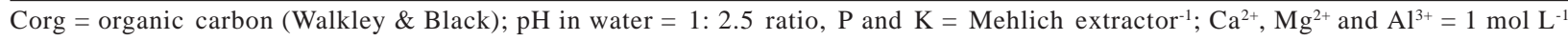
$\mathrm{KCl}$ extractor, $\mathrm{H}+\mathrm{Al}=0.5 \mathrm{~mol} \mathrm{~L}{ }^{-1} \mathrm{CaOAc}$ extractor at $\mathrm{pH} 7.0 ; \mathrm{SB}=\mathrm{K}^{+}+\mathrm{Ca}^{2+}+\mathrm{Mg}^{2+}+\mathrm{Na}^{+}$; $\mathrm{T}$ and $\mathrm{t}=$ effective cation exchange capacity and at $\mathrm{pH} 7.0$, respectively, $\mathrm{m}=\mathrm{Al}^{3+}$ saturation; $\mathrm{V}=$ base saturation. 
tal variable, as well as Pearson's linear correlations for some variables. Correlation estimates were subjected to F test with 1 and 5\% probability levels (Steel \& Torrie, 1960). Bioactivity of Arabidopsis as a function of humic acids rates was examined by the regression analysis, and the models were chosen based on the response shapes described by Baldotto et al. (2009), significance of regression coefficients and coefficient of determination. Growth rates and concentrations of humic acids correponding to the points of maximum in the response curves were estimated based on the regression equations. The increase rates as a function of humic acids concentrations were estimated by the slope of the curves.

\section{RESULTS}

All samples of humic acids isolated from typical soils of the North Fluminense showed the capacity to stimulate root growth in Arabidopsis higher than the control (Table 2), for example, in Figure 1, humic acids isolated from
A

B
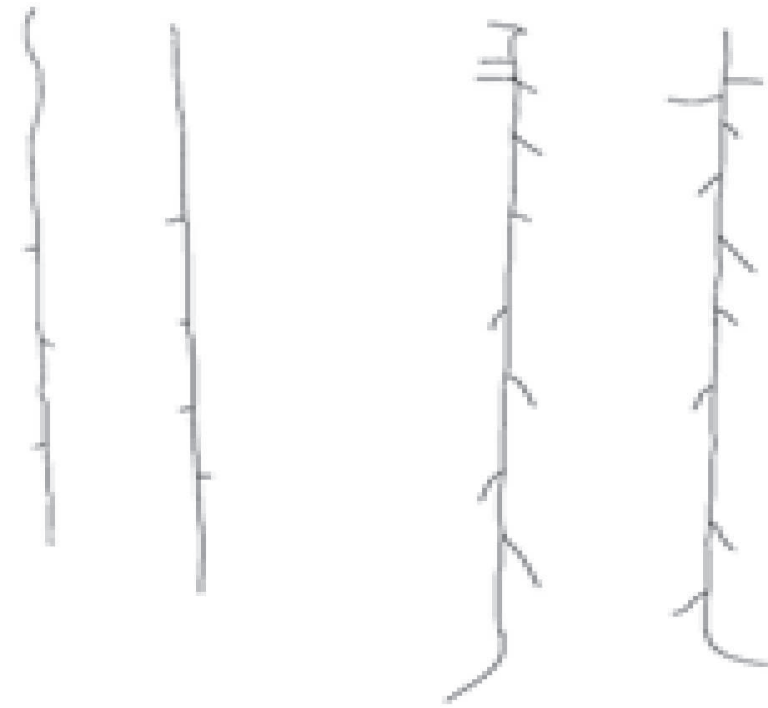

Figure 1. Root growth in Arabidopsis thaliana. Control sample (A) and plant treated with humic acids (B) isolated from the A horizon of a typical Chernosol of the State of Rio de Janeiro.

Table 2. Root growth of Arabidopsis thaliana treated with humic acids (HA) isolated from typical soils of the State of Rio de Janeiro

\begin{tabular}{|c|c|c|c|c|c|c|c|c|}
\hline \multirow{2}{*}{ Soil class } & \multirow{2}{*}{ Horizon } & \multirow{2}{*}{ HA } & \multicolumn{2}{|c|}{ NLR ${ }^{(1)}$} & \multicolumn{2}{|c|}{$\mathbf{L L R}^{(2)}$} & \multicolumn{2}{|c|}{$\mathbf{L M R} \mathbf{R}^{(3)}$} \\
\hline & & & Mean & SEM & Mean & SEM & Mean & SEM \\
\hline & \multicolumn{4}{|c|}{$-\mathrm{mg} \mathrm{L}^{-1}-$} & . & 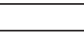 & 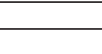 & . \\
\hline Control & - & 0 & 3.2 & 0.3 & 100 & 0 & 100 & 0 \\
\hline \multirow{6}{*}{ Chernosol } & \multirow{3}{*}{ A } & 20 & 6.0 & 0.0 & 231 & 2 & 113 & 3 \\
\hline & & 40 & 9.5 & 0.5 & 254 & 20 & 134 & 5 \\
\hline & & 80 & 9.0 & 0.0 & 200 & 22 & 104 & 3 \\
\hline & \multirow{3}{*}{ B } & 20 & 13.0 & 1.0 & 204 & 19 & 112 & 3 \\
\hline & & 40 & 9.5 & 0.5 & 276 & 6 & 122 & 3 \\
\hline & & 80 & 8.0 & 0.0 & 296 & 4 & 115 & 2 \\
\hline \multirow{6}{*}{ Luvisol } & \multirow{3}{*}{ A } & 20 & 9.0 & 0.0 & 307 & 33 & 95 & 6 \\
\hline & & 40 & 8.5 & 0.5 & 207 & 33 & 115 & 1 \\
\hline & & 80 & 10.0 & 1.0 & 341 & 22 & 112 & 1 \\
\hline & \multirow{3}{*}{ B } & 20 & 6.0 & 1.0 & 211 & 4 & 100 & 1 \\
\hline & & 40 & 10.5 & 1.5 & 446 & 2 & 130 & 4 \\
\hline & & 80 & 9.5 & 1.5 & 291 & 91 & 132 & 4 \\
\hline \multirow{6}{*}{ Acrisol } & \multirow{3}{*}{$\mathrm{A}$} & 20 & 4.5 & 0.5 & 120 & 2 & 148 & 3 \\
\hline & & 40 & 4.5 & 0.5 & 159 & 19 & 153 & 4 \\
\hline & & 80 & 5.5 & 1.5 & 146 & 6 & 139 & 3 \\
\hline & \multirow{3}{*}{ B } & 20 & 7.5 & 0.5 & 163 & 19 & 162 & 1 \\
\hline & & 40 & 5.0 & 0.0 & 93 & 4 & 121 & 5 \\
\hline & & 80 & 4.5 & 0.5 & 135 & 6 & 165 & 2 \\
\hline \multirow{6}{*}{ Latosol } & \multirow{3}{*}{ A } & 20 & 7.5 & 0.5 & 180 & 6 & 130 & 6 \\
\hline & & 40 & 8.0 & 0.0 & 154 & 9 & 140 & 0 \\
\hline & & 80 & 6.0 & 1.0 & 172 & 17 & 91 & 4 \\
\hline & \multirow{3}{*}{ B } & 20 & 10.0 & 1.0 & 78 & 4 & 119 & 1 \\
\hline & & 40 & 9.0 & 0.0 & 119 & 4 & 125 & 0 \\
\hline & & 80 & 10.0 & 1.0 & 109 & 20 & 135 & 0 \\
\hline
\end{tabular}

(1) NLR = number of lateral roots, (2) LLR = length of lateral roots, (3) LMR = length of main root; Means are followed by their respective standard errors $(\mathrm{SEM})$. 
Chernosol. Stimuli was dependent on the concentrations applied in the treatments. In general, curvilinear increases were observed in growth rates of Arabidopsis' root as a function of the concentrations of humic acids isolated from soils (Table 3). The response curves to the application of increasing concentrations of humic acids showed quadratic and square root variation, being evidence for the dose-dependent effect of humic acids in plant development. These response curves resulted in a significant increase over the control to a peak and then decrease as higher concentrations of humic acids were applied. The increase in Arabidopsis' root growth rate with the concentrations of humic acids was different in each evaluated soil class and horizons.

Table 4 shows the results of growth rates for Arabidoposis' root system as a function of humic acids concentrations. The number of lateral roots, maximum lengths of main and lateral roots and the humic acids concentrations varied with the origin of humic acids.

At the point of maximum, on average, the number of lateral roots in plants treated with humic acids increased by $148 \%$ compared with the control, with responses in the following order: Acrisol $\mathrm{B}<$ Acrisol $\mathrm{A}=$ Latosol $\mathrm{A}<\mathrm{Latosol}$ $\mathrm{B}=$ Luvisol $\mathrm{A}=$ Luvisol $\mathrm{B}<\mathrm{Chernosol} \mathrm{A} \cong$ Chernosol $\mathrm{B}$.

The length of these lateral roots, in general, in plants treated with humic acids, was on average 104\% higher than the control plants, in the following order: Acrisol B < Latosol B < Latosol B Acrisol A < Chernosol A < Chernosol B < Luvisol B < Luvisol A. The length of the main root was the variable that showed the least change, with a mean increase of $26 \%$ in treatments with humic acid compared with the control, with the means following the order: Luvisol $\mathrm{A}<\mathrm{Chernosol} \mathrm{A} \cong$ Luvisol $\mathrm{B}<$ Latosol $\mathrm{B} \cong$ Latosol $\mathrm{A} \cong$ Chernosol $\mathrm{B}<\mathrm{Acrisol} \mathrm{A} \cong$ Acrisol $\mathrm{B}$.

Table 3. Regression equations for root growth of Arabidopsis thaliana treated with humic acids (HA) isolated from typical soils of the State of Rio de Janeiro

\begin{tabular}{|c|c|c|c|}
\hline \multicolumn{2}{|c|}{ Soil class ${ }^{(1)}$} & \multirow[t]{2}{*}{ Regression equation } & \multirow[t]{2}{*}{$\mathbf{R}^{2}$} \\
\hline Sample & Horizon & & \\
\hline \multicolumn{4}{|c|}{ Number of lateral roots } \\
\hline \multirow[t]{2}{*}{ Chernosol } & A & $\hat{\mathrm{y}}=2.907+0.226^{* *} \mathrm{x}-0.001 * * \mathrm{x}^{2}$ & 0.968 \\
\hline & $\mathrm{B}$ & $\hat{y}=4.407+0.339 * x-0.003 * x^{2}$ & 0.623 \\
\hline \multirow[t]{2}{*}{ Luvisol } & A & $\hat{y}=3.753+0.220 * x-0.001 * x^{2}$ & 0.850 \\
\hline & $\mathrm{B}$ & $\hat{y}=2.757+0.260 * * x-0.002 * * x^{2}$ & 0.939 \\
\hline \multirow[t]{2}{*}{ Acrisol } & A & $\hat{y}=3.500+0.026^{\circ} x$ & 0.873 \\
\hline & $\mathrm{B}$ & $\hat{\mathrm{y}}=3.312+1.334 * * \mathrm{x}^{0.5}-0.139 * * \mathrm{x}$ & 0.738 \\
\hline \multirow[t]{2}{*}{ Latosol } & A & $\hat{\mathrm{y}}=3.398+0.221 * * \mathrm{x}-0.002 * * \mathrm{x}^{2}$ & 0.953 \\
\hline & $\mathrm{B}$ & $\hat{y}=3.889+0.254 * * x-0.002 * * x^{2}$ & 0.802 \\
\hline \multicolumn{4}{|c|}{ Length of lateral roots ( $\%$ in relation to control) } \\
\hline \multirow[t]{2}{*}{ Chernosol } & A & $\hat{y}=106.20+6.85^{* *} \mathrm{x}-0.071^{* *} \mathrm{x}^{2}$ & 0.965 \\
\hline & $\mathrm{B}$ & $\hat{y}=99.19+6.290 * * x-0.047 * x^{2}$ & 0.999 \\
\hline \multirow[t]{2}{*}{ Luvisol } & A & $\hat{y}=134.20+6.640^{\circ} x-0.027^{\circ} x^{2}$ & 0.594 \\
\hline & $\mathrm{B}$ & $\hat{\mathrm{y}}=72.77+13.11 * * \mathrm{x}-0.128 * * \mathrm{x}^{2}$ & 0.857 \\
\hline \multirow[t]{2}{*}{ Acrisol } & A & $\hat{y}=96.01+2.12^{(0.31)} x-0.018^{(0.18)} x^{2}$ & 0.907 \\
\hline & $\mathrm{B}$ & $\mathrm{w}=\overline{\mathrm{y}}=102$ & \\
\hline \multirow[t]{2}{*}{ Latosol } & $\mathrm{A}$ & $\hat{y}=110.50+2.49^{(0.26)} x-0.022^{(0.12)} x^{2}$ & 0.648 \\
\hline & $\mathrm{B}$ & $\hat{y}=\bar{y}=123$ & \\
\hline \multicolumn{4}{|c|}{ Length of main root (\%in relation to control) } \\
\hline \multirow[t]{2}{*}{ Chernosol } & A & $\hat{y}=97.38+1.456 * * x-0.017 * * x^{2}$ & 0.876 \\
\hline & $\mathrm{B}$ & $\hat{y}=99.40+0.857 * * x-0.008 * * x^{2}$ & 0.982 \\
\hline \multirow[t]{2}{*}{ Luvisol } & A & $\hat{y}=98.47+0.203^{\circ} x$ & 0.542 \\
\hline & $\mathrm{B}$ & $\hat{y}=99.55+0.455^{* *} x$ & 0.760 \\
\hline \multirow[t]{2}{*}{ Acrisol } & $\mathrm{A}$ & $\hat{\mathrm{y}}=102.70+2.380 * * \mathrm{x}-0.024 * * \mathrm{x}^{2}$ & 0.945 \\
\hline & $\mathrm{B}$ & $\hat{y}=103.35+10.10^{\circ} x^{0.5}-0.046 x$ & 0.548 \\
\hline \multirow[t]{2}{*}{ Latosol } & A & $\hat{y}=99.79+2.090^{* *} \mathrm{x}-0.027 * * \mathrm{x}^{2}$ & 0.999 \\
\hline & $\mathrm{B}$ & $\hat{\mathrm{y}}=100.90+0.871^{* *} \mathrm{x}-0.005^{* *} \mathrm{x}^{2}$ & 0.984 \\
\hline
\end{tabular}

(1) A and B refer to horizons dominated by characteristics obtained from the environment and the genetic characteristics, respectively, ${ }^{(\mathrm{P})}$, ${ }^{\circ}, *$ and $* *=$ significant at $\mathrm{P}, 10,5$ and $1 \%$ probability respectively. 


\section{DISCUSSION}

Humic acids isolated from typical soils of the North Fluminense region promoted distinct physiological changes in Arabidopsis compared with the control.

Humic acids, despite their size, have a relatively high mass, which would limit its entry into the plant cell. One hypothesis for the beneficial effect generated by these humified fractions of soil organic matter on plant growth is their role in plant metabolism through molecular signaling processes analogous to those of hormones. Canellas et al. (2002) found that sub-structural units of humic acids were able to access receptors on the surface or inside the plasma membrane of root cells, stimulating development.

In this study, the maximum increase in formation and length of lateral roots, with the simultaneous lower increase in the main roots of plants treated with humic acids, as compared with the control, were, in general, in the following order: Luvisol $>$ Chernosol $>$ Acrisol $\sim$ Latosol. For comparison of the effects of humic acids with effects of growth regulators, we determined the correlation between the length of lateral roots and length of main root, which was negative and significant $\left(R=-0.73^{\mathrm{P}<0.05}\right)$. The same behavior, i.e., decrease in the main root and increase in lateral root formation, is reported by studies using auxins as biostimulants (Façanha et al., 2002).

Canellas et al. (2002) reported that the synthesis of plasma membrane enzymes, isolated from corn roots, was correlated with the presence of auxins in humic acids, changing the pattern of root development in seedlings. Zandonadi et al. (2007) and Dobbs et al. (2007) proved that different humic acids are not capable of promote lateral rooting in seedlings of tomato mutants defective for auxin signaling (dgt), making it even more evident the idea that humic acids act similarly to auxin.
The hormone-like effect, especially similar to that of auxins, as discussed by Canellas et al. (2002), Nardi et al. (2005), Zandonadi et al. (2007) and Dobbss et al. (2007), is based on the increase in formation and length of lateral roots in relation to the growth of the main root in plants treated with humic acids. For the Acrisol and Latosol, particularly in subsurface layers, the fertility is limited to the point that humic acids did not provide an effect different from the control. These results suggest the absence of minimum conditions for the formation of chemical-structural bioactive humic acids in these soils. Likewise, indirectly, it can be inferred that the humic precursors found no necessary ambience conducive to similar evolution of humic aggregates among the soils sampled. Soils with the most bioactive humic acids are the most fertile (Table 1).

Humic substances, designated as supramolecular by Piccolo (2001), have the properties of biomolecules from which they are derived (biopolymers), fragments that form an integral or labile part of the molecular architecture and thus control their conformation, chemical reactivity and bioactivity. Additionally, acidification of the humic acids' solution with organic acids of low molecular weight exudated by plant roots can influence the structure and conformation of the supramolecular arrangement of these humic substances with relative disintegration of these clusters, increasing their bioactivity (Piccolo, 2001; Sposito, 2008).

Canellas et al. (2008b) studied the exudation profile of plants treated with humic substances and found a remarkable change: the presence of citric, malic, tartaric and oxalic acids occurred, or was increased in the exudates of corn roots in response to application of humic acids. Chromatographic analysis of these solutions revealed only the presence of substances of low molecular

Table 4. Values of maximum ( $\mathrm{w}_{\text {Max }}$ ) root growth of Arabidopsis thaliana treated with humic acids isolated from typical soils of the State of Rio de Janeiro and concentration for each condition

\begin{tabular}{|c|c|c|c|c|c|c|c|}
\hline \multirow[t]{3}{*}{ Soil class } & \multirow[t]{3}{*}{ Horizon } & \multicolumn{2}{|c|}{$\mathbf{N L R}^{(1)}$} & \multicolumn{2}{|c|}{$\mathbf{L L R}^{(2)}$} & \multicolumn{2}{|c|}{$\mathbf{L M R}^{(3)}$} \\
\hline & & $\hat{y}_{\text {Máx }}$ & Concentration & $\hat{y}_{\text {Máx }}$ & Concentration & $\hat{y}_{\text {Máx }}$ & Concentration \\
\hline & & & $\mathrm{mg} \mathrm{L}^{-1}$ & $\%$ & $\mathrm{mg} \mathrm{L}^{-1}$ & $\%$ & $\mathrm{mg} \mathrm{L}^{-1}$ \\
\hline Control & - & 3.2 & - & 100 & - & 100 & - \\
\hline \multirow[t]{2}{*}{ Chernosol } & A & 12 & 56.5 & 271 & 48.9 & 129 & 42.8 \\
\hline & B & 13 & 20.0 & 308 & 66.9 & 145 & 53.6 \\
\hline \multirow[t]{2}{*}{ Luvisol } & A & 10 & 61.0 & 492 & 80.0 & 112 & 80.0 \\
\hline & $\mathrm{B}$ & 10 & 60.5 & 408 & 51.2 & 132 & 80.0 \\
\hline \multirow[t]{2}{*}{ Acrisol } & $\mathrm{A}$ & 8 & 80.0 & 158 & 58.8 & 162 & 49.6 \\
\hline & $\mathrm{B}$ & 6 & 23.0 & nd & nd & 165 & 80.0 \\
\hline \multirow[t]{2}{*}{ Latosol } & A & 8 & 55.2 & 181 & 56.6 & 140 & 38.7 \\
\hline & B & 10 & 63.5 & $\mathrm{nd}$ & nd & 139 & 80.0 \\
\hline
\end{tabular}

(1) NLR = number of lateral roots, (2) LLR = length of lateral roots, (3) LMR = length of main root; nd = not determined due to lack of fit of regression equations: average of $\mathrm{B}$ Acrisol $=102 \%$ and $\mathrm{B}$ Latosol $=123 \%$. 
weight, indicating the division of humic acids aggregates initially applied, confirming the conceptual model presented by Piccolo (2001). In this context, similar to the results of root growth observed here, Nardi et al. (2002), Canellas et al. (2002, 2008a, b), Zandonadi et al. (2007) and Baldotto et al. (2009) observed biostimulant effects of humic acids, which can be explained by their nature as providers of polymers conceptualized by Sposito (2008). The release of these biostimulant substances by humic acids, in the rhizosphere, is associated with the response of treated plants in the form of exudation of organic acids. The humic acids isolated from the Acrisol and Latosol, whose growth responses did not differ from the control, do not contain such biostimulants. Considering that the same vegetation cover contributes similarly as a source of organic matter, it can be inferred that the different humic acids components of each soil do not allow similar storage of such bioactive substances in the supramolecule. The chemical structural aspects of the same humic acids were studied by Canellas et al. (2008a) and Baldotto et al. (2009). The results indicated that humic acids of the Chernosol and Luvisol are more humified, hydrophobic and stable than those of the Acrisol and Latosol.

According to Sposito (2008), the protection of organic matter by coating clay particles is one of the main mechanisms of stabilization and accumulation of humic substances in natural systems. Ion exchange reactions and interactions as hydrogen bonds, unstable water molecules forming Lewis acids (water bridging) and van der Waals forces occur between these mineral components and units of polar and nonpolar organic substances. Such mechanisms are consistent with the close relationship between the colloidal mineral activity, stability, and ability to stimulate plants as found in this study.

Two findings can be highlighted: i) the formation of a humic aggregate stable and bioactive are similar and require contact with clay silicates $2: 1$ of high ion-exchange capacity and eutrophic, and ii) recent studies on humic substances (Piccolo, 2001) indicate that despite they have high molecular weight as in polymers, their structure consists of complex associations of heterogeneous molecules, stabilized by hydrophobic interactions with apparent high molecular weight. Also, biopolymers, derived from plant residues and microbial activity, are incorporated into more stable fractions of the humified organic matter and it is related to the quality of its ambience (Canellas et al., 2008a). Thus, we found that the hydrophobicity of humic acids, inversely correlated with the stage of soil weathering, was the mechanism responsible for the preservation of organic substances capable of positively stimulating root growth of
Arabidopsis, activating $\mathrm{H}^{+}$-ATPases, promoting plasma membrane depolarization and, thereby, activating secondary transporters responsible for the increase in absorption of macro and micronutrients (Canellas et al., 2002, Sondergaard et al. 2004; Canellas et al., 2008a).

\section{CONCLUSIONS}

All humic acids studied stimulated the root growth of Arabidopsis thaliana in relation to control.

More stable humic acids isolated from soil in less advanced stages of weathering, with high-activity clays and high base saturation were the best physiological stimulants of Arabidopsis.

Increases in formation and length of lateral roots in relation to the main root length of plants treated with humic acids compared with the control were found in the following order: Luvisol $\geq$ Chernosol $>$ Acrisol $\geq$ Latosol.

In addition to the dependence on the soil class, there were higher differences in Arabidopsis' physiological response as a function of concentrations of humic acids than in response to the horizon sampled within the soil class.

The mean concentration to achieve the maximum values for the variables number and length of lateral roots and length of the main root was approximately $60 \mathrm{mg} \mathrm{L}^{-1}$ of humic acids.

\section{ACKNOWLEDGEMENTS}

This work was financially supported by the Project "Quality of Organic Matter in Soils of the State of Rio de Janeiro - Basis for Environmental Protection and Sustainable Agricultural Production" (FAPERJ Proc. E26/153.086/2006 and E-26/110.633 / 2007) and a PostDoctoral Fellowship from CNPq ((556160/2006-1) to the first author.

\section{REFERENCES}

Baldotto MAB, Canela MC, Dobbss LB, Canellas LP, Velloso ACX (2010) Redox index of soil carbon stability. Revista Brasileira de Ciência do Solo, 35: 1543-1551.

Baldotto LEB, Baldotto MA, Giro VB, Canellas LP, Olivares FL \& Bressan-Smith R (2009) Desempenho do abacaxizeiro 'Vitória' em resposta à aplicação de ácidos húmicos durante a aclimatação. Revista Brasileira de Ciência do Solo, 33: 979990 .

Canellas LP, Façanha AO, Façanha AR \& Olivares FL (2002) Humic acids isolated from earthworm induces root mitotic sites and plasma membrane $\mathrm{H}^{+}$-ATPase. Plant Physiology, 30: 19511957.

Canellas LP \& Façanha AR (2004) Relantionship between chemical nature of soil humifield fractions and their bioactivity. Pesquisa Agropecuária Brasileira, 39: 233- 240. 
Canellas LP, Zandonadi DB, Olivares FL \& Façanha AR (2006) Efeitos fisiológicos de substâncias húmicas - o estímulo às $\mathrm{H}^{+}$ ATPases. In: Fernandes MS (Ed.) Nutrição Mineral de Plantas. v.1. Viçosa: Sociedade Brasileira de Ciência do Solo. p. 175-200.

Canellas LP, Zandonadi DB, Busato JG, Baldotto MA, Simões ML, Martin-Neto L, Façanha AR, Spaccini R \& Piccolo A (2008a) Bioactivity abd chemical characteristics of humic acids from tropical soils sequence. Soil Science, 173: 624-637.

Canellas LP, Teixeira Junior LRL, Dobbss LB, Silva CA, Medici LO, Zandonadi DB \& Façanha AR (2008b) Humic acids crossinteractions with root and organic acids. Annals of Applied Biology, 1: 1-10.

Chen Y \& Avaid T (1990) Effects of humic substances on plant growth. In: MaCcarthy P; Capp CE; Malcolm RL \& BLOOM PR (Ed.) Humic substances in soil and crop sciences: selected readings. Madison, American Society of America. p.161-186.

Chen Y, Clapp CE \& Magen H (2004) Mechanisms of plant growth stimulation by humic substances: The role of organo-iron complexes. Soil Science and Plant Nutrition, 50:1089-1095.

Delfine S, Tognetti R, Desiderio E \& Alvino A (2005) Effects of foliar application of $\mathrm{N}$ and humic acids on growth and yield of durum wheat. Agronomy for Sustainable Development, 25:183191.

Dobbss LB, Medici LO, Peres LEP, Pino-Nunes LE, Rumjanek VM, Façanha AR \& Canellas LP (2007) Changes in root development of Arabidopsis promoted by organic matter from oxisols. Annals Applied Biology, 151: 199-211.

Empresa Brasileira de Pesquisa Agropecuária - Embrapa (1980) I Reunião de Classificação e Correlação de Solos do Estado do Rio de Janeiro: Serviço Nacional de Levantamento e Conservação de Solos. (EMBRAPA-SNLCS. Boletim Técnico, 62). 79p.

Empresa Brasileira de Pesquisa Agropecuária - Embrapa (2006) Sistema Brasileiro de Classificação de Solos. 2.ed. Rio de Janeiro: Centro Nacional de Pesquisa em Solos. 412p.

Façanha AR, Façanha ALO, Olivares FL, Guridi F, Santos GA, Velloso ACX, Rumjanek VM, Brasil F, Schripsema J, Braz-Filho R, Oliveira MA \& Canellas LP (2002) Bioatividade de ácidos húmicos: Efeito sobre o desenvolvimento radicular e sobre a bomba de prótons da membrana plasmática. Pesquisa Agropecuária Brasileira, 37: 1301-1310.

Ferrara G \& Brunetti G (2008) Influence of foliar applications of humic acids on yield and fruit quality of table grape cv. Itália. Journal International des Sciences de la Vigne et du Vin, 42:7987.

Frias I, Caldeira MT, Perez Castineira JR, Avarro Avino JP, Culianez Macia FA, Kuppinger O, Stransky H, Pages M, Hager A \& Serrano $\mathrm{R}$ (1996) A major isoform of the maize plasma membrane $\mathrm{H}^{+}$-ATPase, characterization and induction by auxin in coleoptiles. Plant Cell, 8: 1533-1544.
Hager A, Debus G, Edel HG, Stransky H \& Serrano R (1991) Auxin induces exocytosis and rapid synthesis of a high-turnover pool of plasma-membrane $\mathrm{H}^{+}$-ATPase. Planta, 185: 527-537.

International Humic Substances Society-IHSS (2009) Products. Disponível em: 〈http://www.ihss.gatech.edu/products.html> Acessado em 20 junho. 2009.

Nardi S, Pizzeghello D, Muscolo A \& Vianello A (2002) Physiological effects of humic substances in higher plants. Soil Biology and Biochemistry, 34:1527-1537.

Nardi S, L'osoni M, Pizzeghello D, Provenzano MR, Cilenti A, Sturaro A, Rella R, Vianello A (2005) Chemical characteristics and biological activity of organic substances extracted from soils by root exudates. Soil Science Societ American, 369: 3122019.

Piccolo A (2001) The supramolecular structure of humic substances. Soil Science, 166: 810-832.

Rodda MRC, Canellas LP, Façanha AR, Zandonadi DB, Almeida DL, Guerra JGM \& Santos GA (2006) Estímulo no crescimento e na hidrólise de ATP em raízes de alface tratadas com humatos de vermicomposto. I - efeito da concentração Revista Brasileira de Ciência do Solo, 30: 649-656.

Sommerville CR \& Meyerowitz EM (eds.) (2002) The Arabidopsis Book. Rockville: American Society of Plant Biologists, 320p.

Sondegaard TE, Schulza A \& Palmgren MG (2004) Energization of transport processes in plants. Roles of plasma membrane $\mathrm{H}^{+}$ATPase. Plant Physiology, 136:2475-2482.

Sposito G (2008) The chemistry of soils. 2. ed. New York: University Oxford Press. 329p.

Steel RGD \& Torrie JH (1960) Principles and procedures of staristics with special referende to the biological sciences. McGraw-Hill Book Company, New York, 453p.

Tejada M \& Gonzalez JL (2004) Effect of foliar application of a byproduct of the two-step olive oil mill process on rice yield. European Journal of Agronomy, 21:31-40.

Vaughan D \& Malcolm RE (1985) Influence of humic substances on growth and physiological process. In: Vaughan D \& Malcolm RE (Eds.) Soil organic matter and biological activity. Dordrecht: Kluwer Academic. p. 37-75.

Zandonadi DB, Canellas LP \& Façanha AR (2007) Indolacetic and humic acids induce lateral root development through a concerted plasmalemma and tonoplast $\mathrm{H}^{+}$pumps activation. Planta, 225:1583-1595. 